Studia Oecumenica 17 (2017)

DOI: $10.25167 / \mathrm{SOe} / 17 / 2017 / 69-78$

WOJCIECH HANC

Wydział Teologiczny UKSW

\title{
Marcin Luter z perspektywy ekumenicznych dialogów
}

\author{
Martin Luther in the Perspective of the Ecumenical Dialogues
}

\begin{abstract}
Year 2017 marked by the $500^{\text {th }}$ anniversary of Reformation would not exist without the seminal figure - the author of the unusual event in the history of the universal Church - that is considered the cause of schism in the Western Church. The event is presented in the light of the $50^{\text {th }}$ anniversary of the inter-confessional ecumenical Lutheran-Catholic dialogues, among which the specific importance of the Report of the Lutheran-Roman Catholic Commission for Unity From Conflict to Communion (2013), is to be noted. The report deals with the Catholic-Lutheran commemoration of the Reformation in 2017. By taking into consideration various ecumenical dialogues, author of the paper decides to ask about the true image of dr Martin Luther and attempts to present him as a "witness of the Gospel and witness of Jesus Christ. At the end of his analysis, the author attempts to answer a question: who really was, and is today, Martin Luther.
\end{abstract}

Keywords: Martin Luther, Reformation, doctrinal dialogues.

\section{Streszczenie}

Rok 2017 - brzemienny w wydarzenie 500-lecia Reformacji - nie mógłby zaistnieć bez czołowej postaci, którą stanowi główny autor tego niezwykłego zdarzenia w dziejach Kościoła powszechnego, i której przypisuje się rozłam w łonie Kościoła zachodniego. Przedstawiający owo wydarzenie stara się to uczynić w 50-lecie międzywyznaniowych dialogów ekumenicznych luterańsko-katolickich, spośród których znaczący impuls należy odnieść do raportu luterańsko-rzymskokatolickiej Komisji Dialogu ds. Jedności $O d$ konfliktu do komunii (2013), będący zarazem katolicko-luterańskim upamiętnieniem Reformacji w 2017 r. Stąd autor artykułu stara się na kanwie kilku dialogów ekumenicznych postawić pytanie o prawdziwy obraz dr. Marcina Lutra, zarysować głównego reformatora jako „świadka Ewangelii i świadka Jezusa Chrystusa” oraz podsumować całość przedłożenia, podejmując próbę odpowiedzi na pytanie: Kim właściwie był i kim jest dzisiaj Marcin Luter?

Słowa kluczowe: Marcin Luter, Reformacja, dialogi doktrynalne.

Spośród jedenastu raportów bilateralnego dialogu luterańsko-rzymskokatolickiego na forum światowym, jakie na przestrzeni pięćdziesięciu lat wypracowa- 
no ${ }^{1}$, przedmiotem niniejszej refleksji będą zasadniczo dwa dokumenty dialogowe: pierwszy, Marcin Luter - świadek Jezusa Chrystusa, zawiera uzgodnienie Wspólnej Komisji rzymskokatolickiej oraz ewangelicko-luterańskiej z okazji 500-lecia urodzin dra Marcina Lutra (1983). Dokument ten jest doskonałym wprowadzeniem do drugiego raportu luterańsko-rzymskokatolickiej Komisji Dialogu ds. Jedności Od konfliktu do komunii, stanowiącym „Luterańsko-Katolickie Wspólne Upamiętnienie Reformacji w roku 2017”. Uzgodnienie to opublikowano w $2013 \mathrm{r}$.

Biorąc do ręki dokument pierwszy, już na samym początku rzuca się w oczy jego Przedmowa, której autorami są: katolicki biskup H.L. Martensen oraz luterański prof. G.A. Lindbeck, zwracający naszą uwagę na fakt, iż Wspólna Komisja, mająca na uwadze „starania w poszukiwaniu dróg do wspólnoty wiary”, zajmowała się już wielokrotnie Reformacją oraz osobą i dziełem Marcina Lutra, ponieważ z okazji 450-tej rocznicy Konfesji Augsburskiej w 1980 r. stwierdzono, że znajdujemy się „wszyscy pod jednym Chrystusem”, dlatego w podstawowych prawdach wiary możliwe jest już dawanie wspólnego świadectwa ${ }^{2}$. Natomiast 500. rocznica urodzin Marcina Lutra kierowała uwagę Komisji dialogowej „do refleksji nad osobą i dążeniami Reformatora oraz do opublikowania wspólnego Słowa, które winno służyć pojednaniu i porozumieniu". Dlatego ten tekst zamierzał wyeksponować pewne istotne zamiary Reformatora oraz pokazać jego postać w ekumenicznym profilu. Ponadto w dokumencie tym chodziło o zwrócenie uwagi na zmianę świadomości, jaka się dokonała dzięki ewangelickim i katolickim badaniom, przyczyniając się w ten sposób do przezwyciężenia często funkcjonującego w przeszłości spaczonego obrazu Lutra ${ }^{3}$. Przy czym zarówno dokument z 1983, jak i 2013 r. kieruje swoje spojrzenie nie tylko na sam obraz

${ }^{1}$ Dialogi powyższe były prowadzone w toku czterech faz: faza 1: Ewangelia i Kościót (Raport z Malty - 1972); faza 2: Wieczerza Pańska (1978), Drogi do Wspólnoty (1980), Wszyscy pod jednym Chrystusem (1980), Urząd duchownego w Kościele (1981), Marcin Luter - świadek Jezusa Chrystusa (1983), Jedność przed nami (1984); faza 3: Kościót i usprawiedliwienie (1993); faza 4: Apostolskość Kościoła (2006) oraz wypracowana Wspólna deklaracja w sprawie nauki o usprawiedliwieniu, podpisana przez przedstawicieli Kościoła rzymskokatolickiego oraz Światowej Federacji Luterańskiej 31 października 1999 r. Ostatnim raportem Luterańsko-Rzymskokatolickiej Komisji Dialogu ds. Jedności jest Od konfliktu do komunii. Luterańsko-katolickie wspólne upamiętnienie Reformacji w 2017 roku, wyd. drugie poprawione, Dzięgielów 2017 (thumaczenia dokonano na podstawie: Vom Konflikt zur Gemeinschaft. Gemeinsames lutherisch-katholisches Reformationsgedenken im Jahr 2017. Bericht der Lutherisch-Römisch-katholischen Kommission für die Einheit, Leipzig - Paderborn 2013, oraz: From Conflict to Communion. Lutheran-Catholic Common Commemoration of the Reformation in 2017. Report of the Lutheran-Roman Catholic Commission on Unity, Leipzig - Paderborn 2013).

${ }^{2}$ Zob. Wszyscy pod jednym Chrystusem. Stanowisko Wspólnej Komisji Rzymskokatolicko-Ewangelicko-luterańskiej wobec Konfesji Augsburskiej (1980), w: K. KARSKI, S.C. NAPIÓRKOwSKI (red.), Bliżej wspólnoty. Katolicy i luteranie w dialogu 1965-2000, Lublin 2003, 229-236.

${ }^{3}$ Marcin Luter - świadek Jezusa Chrystusa. Stowo Wspólnej Komisji Rzymskokatolicko-Ewangelicko-luterańskiej z okazji 500-lecia urodzin Marcina Lutra (1983), w: K. KARSKI, S.C. NAPIÓRKOWSKI (red.), Blizej wspólnoty, 273. 
wittenberskiego Reformatora, domagający się odejścia od obciążonego wrogim nastawieniem, jak i wszechobecnie panującą w przeszłości polemiczną metodą, która nie ominęła ani życia, ani nauczania, ani krańcowo ocenianego na przestrzeni wieków przez katolików Marcina Lutra, któremu przypisywano rozbicie Kościoła zachodniego wraz z uporczywym trwaniem w swych głoszonych błędach. Z drugiej strony (ewangelickiej) miała miejsce nie tylko gloryfikacja Reformatora będącego herosem wiary, a zwłaszcza założycielem nowego Kościoła, z czym wiązały się oskarżenia i wydawane, niezgodnie z prawdą, osądy kierowane pod adresem innych Kościołów. Powyższe więc trendy zostały nam przypomniane - jak się wydaje - gwoli refleksji i zadumy, zawarte tak w jednym, jak i w drugim dokumencie, chociaż w nieco innych proporcjach i w innym ukierunkowaniu. Zarówno pierwszy, jak i drugi ze wspomnianych dokumentów wołają o konieczność ponownego nawrócenia i ponownej reformy. Domaga się tego zresztą wyrażona zachęta do dalszego kontynuowania tak przez katolików, jak i ewangelików dwustronnych i wielostronnych dialogów, co się winno czynić pod stałą asystencją i opieką Bożego Ducha ${ }^{4}$.

\section{Pytania o prawdziwy obraz Marcina Lutra}

Pytania o prawdziwy obraz dr. Marcina Lutra, to pytania o obiektywne i trafne oceny tyczące się Reformatora jako postaci historycznej, jako religijnego myśliciela i teologa, czerpiącego całą garścią wskazania zawarte na kartach Biblii, bo czego jak czego, ale tego nie da się dr. M. Lutrowi odmówić. Oto pewne ilustracje, czynione na kanwie jego twórczych wysiłków, bogatego życia i bycia konsekwentnym w swoim myśleniu i działaniu. Otóż angielski katolik i historyk John M. Todd, napisał studium biograficzne o Marcinie Lutrze, gdzie w podsumowaniu dochodzi do następującej konstatacji: „Starałem się wybrać fakty i opinie, aby dać prawdziwy obraz Marcina Lutra (...). Historia Lutra jest historią wymiany poglądów z tymi ludźmi, z którymi się nie zgadzał, historią dialogu i walki. Ale badania nad tą wymianą poglądów i nad wszystkimi faktami z jego życia powinny wspomagać studium ekumeniczne. Należy skończyć ze schematami: Luter - wielki łotr i Luter - wielki bohater. Był zakonnikiem augustiańskim, obdarzonym wielkim intelektem, pobożnym, przeżywającym w dziedzinie życia duchowego głęboki niepokój, człowiekiem pragnącym rozwiązywać swe osobiste dylematy w kontekście nowo przemyślanej teologii biblijnej. Teologia ta zaprowadziła go do gwałtownego wystąpienia przeciwko ówczesnym, powierzchownym i legalistycznym praktykom religijnym. Luter stał się przywódcą reli-

\footnotetext{
${ }^{4}$ Por. Tamże, nr 1-6, oraz Wprowadzenie, w: Od konfliktu do komunii, nr 1-3.
} 
gijnego oderwania się Europy od zachodniego Kościoła rzymskiego, oderwania, które było początkiem protestantyzmu"s.

Wnikając $\mathrm{w}$ treść wymienionych na początku dwu dokumentów dialogowych, stanowiących kanwę dla naszych refleksji, celem uplastycznienia nasuwa się w tym miejscu jeszcze jeden epizod, przywołany przez ks. prof. Wincentego Granata, związany z jego wykładem, dotyczącym dr. Marcina Lutra i wydarzenia związanego z jego osobą, czyli z Reformacją. Profesor Granat, w którego zajęciach z zakresu teologii dogmatycznej brałem udział, w tym w seminarium doktoranckim, wspomniał wykład o. prof. Y. Congara, wybitnego dominikańskiego teologa, który chcąc dotrzeć do źródeł związanych z życiem Reformatora i wydarzeniem Reformacji, spędził wiele miesięcy w niemieckich archiwach, m.in. w Wittenberdze, Wormacji i Berlinie, by się przekonać, czy stawiane Lutrowi zarzuty mają pokrycie w rzeczywistości. Prof. Y. Congar na stawiane przez studentów pytania powiedział m.in., że po kilkunastumiesięcznych badaniach materiałów źródłowych doszedł do odmiennego niż inni wniosku, mówiąc, że „to dziecko ma innego ojca, a jest nim niezwykłe zło, które w Kościele się wówczas rozprzestrzeniało"6. Otóż Y. Congar o Marcinie Lutrze m.in. tak się wyraził: „Ten człowiek to jeden $\mathrm{z}$ największych geniuszy w dziejach. $\mathrm{Z}$ tego powodu stawiam go na równi ze św. Augustynem, św. Tomaszem i Pascalem (...). Był człowiekiem, który przemyślał całe chrześcijaństwo. Stworzył nową syntezę, nową interpretację. Ten człowiek, zakorzeniony w średniowieczu, wykroczył poza średniowieczny świat. Luter był człowiekiem Kościoła; miał wykształcenie teologiczne i bardzo głębokie doświadczenie katolickie. I poza wszystko wykroczył, ożywiony ogromną twórczą energią"7.

\section{Marcin Luter - świadek Ewangelii i świadek Jezusa Chrystusa}

Już z okazji 500-lecia urodzin dr. Marcina Lutra m.in. stwierdzono, że „ani ewangelickie, ani katolickie chrześcijaństwo nie może przejść obojętnie obok postaci i orędzia tego człowieka”". Zresztą od początku zaistnienia „ruchu ekumenicznego" u progu XX w. nie tylko zaczęto zmieniać tonacje wypowiedzi związane z osobą i dziełem Reformatora, włącznie z pojawiającymi się w tym

5 J.M. Todd, Marcin Luter, Warszawa 1983, 263-264.

${ }^{6}$ Wydarzenie odtworzone z pamięci przez prelegenta.

7 Cyt. za: J.B. Navarro, Luter Marcin, w: TENŻE, Ekumenizm. Mały słownik, Warszawa 2007, 199-201. Przy tej okazji warto zwrócić uwagę choćby na trzy z nader ekumenicznych pozycji Y. Congara: Chrétiens désunis. Principes d'un „oecuménisme catholique”, Paris 1937; Vraie et fausse reforme dans l'Eglise, Paris 1949; Chrétiens en dialogue, Paris 1964.

${ }^{8}$ Marcin Luter - świadek Jezusa Chrystusa, nr 1; por. Od konfliktu do komunii, nr 2. 
względzie przyczynkami naukowymi, i to tak po stronie ewangelickiej, jak i katolickiej, na co bez wątpienia wycisnął swoje znamię coraz bardziej dochodzący do głosu postępujący ruch ekumeniczny, z którym nierozłącznie wiąże się idący w parze ewangelicko-rzymskokatolicki dialog ekumeniczny, przyczyniający się do innego patrzenia na skażony polemiką od ponad czterech wieków wizerunek Reformatora, uważając go w czasach nam współczesnych „za świadka Ewangelii, nauczyciela w dziedzinie wiary i tego, kto nawołuje do duchowej odnowy"9. Zresztą fakt ten nie uszedł uwagi papieża Jana Pawła II, który do rocznicy 500-lecia urodzin Reformatora nawiązał podczas swojej pierwszej wizyty 11 grudnia 1983 r. w luterańskiej świątyni Christus Kirche, kiedy to Biskup Rzymu, po raz pierwszy od czasu Reformacji, wiedziony tchnieniem Ducha Świętego modlił się wspólnie z braćmi luteranami, co stało się w siedem miesięcy i pięć dni po podpisaniu dokumentu dialogowego, uznającego Marcina Lutra jako „świadka Jezusa Chrystusa i Jego Ewangelii"'10.

Autorzy dokumentu dialogowego z 1983 r. po rozdziale pierwszym, nazwijmy go umownie „wprowadzającym”, w drugim rozdziale, składającym się jakby z sześciu odsłon, zarysowali przed naszymi oczyma w świetle luterskich biblijno-teologicznych uzasadnień, jego wewnętrzne przeświadczenie o powołaniu do wypełnienia powierzonych mu zadań, czyli do pełnienia misji, która pozwalała go uważać „za świadka Ewangelii” oraz za „niegodnego ewangelistę Pana naszego Jezusa Chrystusa". Sam Marcin Luter uzasadniał to apostolskim świadectwem biblijnym, do którego interpretacji i przepowiadania jako „doktor Pisma Świętego" był zobowiązany. U podstaw powyższego stawiał starochrześcijańskie wyznanie wiary w Boga Trójjedynego oraz Osoby i dzieła Jezusa Chrystusa, Pana Kościoła, w czym dostrzegał wiążący w tym względzie charakter orędzia biblijnego ${ }^{11}$.

Może zrodzić się pytanie: Co pozwoliło Lutrowi, że mimo trudnych życiowych sytuacji, jak mówi dokument, ,pośród udręk, utrapień i niepewności jego czasów", trwać przy swoich reformatorskich zamierzeniach? Otóż, według autorów dialogowego dokumentu, M. Luter będąc świadomym swej odpowiedzialności za powierzoną mu misję, zawdzięcza owo obstawanie i trwanie ,intensywnej pracy nad Pismem Świętym, którą łączył z osobistymi doświadczeniami, na nowo odkrywając Boże miłosierdzie”. Konkretniej mówiąc, chodzi tu o jego „reformatorskie odkrycie” polegające na odczytaniu w świetle Listu do Rzymian sprawiedliwości Bożej jako „obdarowującej”, a nie „żądającej”, czyli skazującej grzesznika. Przecież Paweł jasno mówił, że „sprawiedliwy z wiary żyje” (Rz

\footnotetext{
9 Marcin Luter - świadek Jezusa Chrystusa, nr 4.

${ }_{10}$ Zob. tamże, rozdział II, nr 7-12.

${ }_{11}$ Por. tamize, nr 7.
} 
1,17), co M. Luter odczytał jako „życie” dzięki Bożemu miłosierdziu, którym Bóg obdarza nas przez Chrystusa. Otóż potwierdzenie tego swojego odkrycia Reformator znalazł - jak wiemy - u św. Augustyna, kiedy to otworzyło się przed nim przesłanie Pisma Świętego w postaci Dobrej Nowiny - Ewangelii, co odczytał jako jednoczesne otworzenie się przed nim rzeczywistości nieba, czyli bram raju" "12. Wyobraźmy to sobie tak: właśnie z tą chwilą nastąpiło u przyszłego Reformatora owo wyrażane greckim słowem eureka! - w postaci sola fide, kiedy to Luter zaczął uważać swoje pisma, przepowiadanie i posługę profesorską za wyraz świadectwa tego właśnie wyzwalającego orędzia biblijnego. Wszystko to zaś razem wzięte, stanowiąc „naukę o usprawiedliwieniu grzesznika przez samą wiarę", stało się finalnym odwzorowaniem jego teologicznej myśli, opartej o eksplikację Biblii. Dzięki temu każdy zatroskany o własne zbawienie, pośród zawirowań, obciążeń ludzkimi przepisami, może odnaleźć dzięki wierze w Ewangelię pewność co do wyzwalającej obietnicy Bożej łaski, czyli sola gratia! I chociaż $\mathrm{w}$ toku podejmowania różnego rodzaju studiów historycznych stwierdzano ujawniającą się już w dyskusjach teologicznych pewną zgodność co do tej podstawowej tezy Lutra, to jednak zostało zagubione i w ferworze ówczesnej polemiki zatraciło swoje właściwe znaczenie, które można by nazwać „najdrogocenniejszą perłą soteriologii Lutra, od której zależy esse Kościoła, czyli casus stantis et cadentis Ecclesiae ${ }^{13}$.

Trzeba powiedzieć, że dopiero w czasach współczesnych otworzono drogę ku wzajemnemu porozumieniu w tym centralnym punkcie poruszonym przez Reformatora, czego wyrazem były takie dokumenty dialogowe, jak Ewangelia $i$ Kościót (1972), co zostało wyrażone we wspólnej katolicko-luterańskiej deklaracji dotyczącej Konfesji Augsburskiej ${ }^{14}$. Dla całości dodać trzeba także najważniejszy $\mathrm{z}$ tej problematyki dokument dialogowy luterańsko-katolicki, jakim była Wspólna deklaracja w sprawie nauki o usprawiedliwieniu z 31 października 1999 r. ${ }^{15}$, będąca w kwestii usprawiedliwienia nie tylko merytorycznym dopełnieniem dokumentu z 1983 r., lecz samoistnym kolejnym opracowaniem, czyli owocem długoletnich przemyśleń zarówno teologów ewangelickich, jak i katolickich, czego nie mogło nie znaleźć uwydatnienia w doktrynalnych przedłożeniach raportu Od konfliktu do komunii, stanowiącego niezwykłe ubogacenie „upamiętnienia”

${ }_{12}$ Marcin Luter - świadek Jezusa Chrystusa, nr 8.

${ }_{13}$ Por. Marcin Luter - świadek Jezusa Chrystusa, nr 9-10; zob. A. Nossol, Ekumeniczne elementy teologii M. Lutra, w: E. OŁtarzewsKa-Wieja (red.), Z problemów Reformacji, t. VI, Bielsko-Biała 1993, 15-16.

${ }^{14}$ Zob. Marcin Luter - świadek Jezusa Chrystusa, nr 11.

${ }_{15}$ Zob. M. NiEMIEc, Nauka o usprawiedliwieniu $w$ dialogu luterańsko-rzymskokatolickim, Bielsko-Biała 2011; Deklaracja o usprawiedliwieniu: historia powstania, tekst deklaracji, opinie, komentarze, Bielsko-Biała 2000. Tekst Wspólnej Deklaracji w sprawie nauki o usprawiedliwieniu cyt. za: A. Nossol, Ekumenizm jako imperatyw chrześcijańskiego sumienia, Opole 2000, 243-254. 
500-lecia Reformacji w kluczowym dla ewangelicyzmu temacie, uważanym od samego początku Reformacji za articulus stantis et cadentis Ecclesiae stanowiący po dziś dzień - jak wspomniano wyżej - casus, niepozwalający jeszcze sporej rzeszy zarówno teologów katolickich, jak i ewangelickich, spokojnie zasypiać. Z ekumenicznego punktu patrzenia było to - jedno z największych osiągnięć w sferze prowadzonych dotąd w ogóle dialogów doktrynalnych, mimo osiągniętego jak stwierdzono - zróżnicowanego konsensu, „zawierającego wspólne wypowiedzi wraz z naświetleniem różnych akcentów postawionych przez każdą ze stron w myśl tezy, że różnice nie dewaluują zagadnień wspólnych dla obydwu tradycji. Chodzi zatem o konsens, który nie wyklucza różnic, lecz je wyraźnie uwzględnia" ${ }^{16}$. Dlatego też w dokumencie Od konfliktu do komunii (przytoczmy tu jedynie w postaci résumé wspólne w tym względzie wyznanie) stwierdzono: „Katolicy i luteranie wspólnie wyznają: «Tylko z łaski i w wierze w zbawcze działanie Chrystusa - a nie na podstawie naszych zasług - zostajemy przyjęci przez Boga i otrzymujemy Ducha Świętego, który odnawia nasze serca, uzdalnia nas i wzywa do dobrych uczynków»" (Wspólna deklaracja, nr 15). I dalej: „Orędzie o usprawiedliwieniu (...) powiada nam, że jako grzesznicy nasze nowe życie zawdzięczamy wyłącznie miłosierdziu Bożemu, które rodzi przebaczenie i wszystko czyni nowe; miłosierdzie to możemy otrzymać jako dar i przyjąć $\mathrm{w}$ wierze, nigdy natomiast - w jakiejkolwiek formie - nie możemy na nie zasłużyć" (tamże, nr 17).

\section{Podsumowanie w postaci końcowego pytania: Kim właściwie był i kim jest dzisiaj dr Marcin Luter?}

Pytanie to doczekało się wielu odpowiedzi, chociaż wciąż jeszcze na dalsze odpowiedzi czekamy. Już G.H. Tavard, jeden z najlepszych za oceanem katolickich specjalistów od spraw Reformacji, przekonywał, że Luter był dzieckiem swego wieku i odziedziczył jego choroby, tak jak my odziedziczyliśmy wady i choroby naszych czasów. Luter dostrzegając u ludzi żyjących w Kościele wiele zła, zwalczał je z podziwu godną odwagą. Na przykład nauką o usprawiedliwieniu przez samą wiarę wcale nie zamierzał doprowadzić do rozłamu w Kościele i teologii, lecz pragnął jedynie oczyścić chrześcijańską pobożność z różnego rodzaju naleciałości (J. Hessen). Działał więc z motywów religijnych (J.M. Todd). Dlatego, by obraz M. Lutra był prawdziwy, nie można oceniać go powierzchownie, na podstawie wrosłych w nasze katolickie myślenie wielowiekowych uprzedzeń, które w pewnych kręgach i społecznościach trwają do dnia

\footnotetext{
16 Od konfliktu do komunii, nr 123.
} 
dzisiejszego. Nowe drogi badań nad dr. Lutrem podejmuje w XX w. Joseph Lortz (1887-1975). Zasłynął on dziełem Die Reformation in Deutschland, które uważane jest za epokowe i przełomowe w badaniach nad Lutrem, a jego obraz jawi się jako nowy i przedstawiony we właściwych sobie ramach. J. Lortz eksponuje zarówno wielkość Lutra, jak i jego jednostronność, w tym także granice reformacyjnego porywu. Poddaje bezlitosnej krytyce stosunki panujące w Kościele późnego średniowiecza, włącznie z nadużyciami w praktyce odpustowej, wypaczeniami pobożności, upadkiem teologii, która w dużej części zapoznała już swoją katolickość. Stąd Lortz mając na uwadze ów smutny obraz wielu nadużyć, charakteryzuje Lutra jako człowieka religijnego. Nie był on ani politykiem, ani mistykiem, ani teologiem systematykiem, ale ,żarliwym głosicielem i wyznawcą Ewangelii”. Zniekształcony Kościół Luter pragnął odnowić w duchu Ewangelii. Przyświecały mu w tym względzie najczystsze zamiary religijne, związane z jego człowieczą naturą. „Walczył o realizację prastarych wartości katolickich, których nie dostrzegał w Kościele i w teologii swoich czasów. Według Lortza „Luter zmógł w sobie katolicyzm, który nie był katolicki”"

Nowe spojrzenie na dra M. Lutra otrzymaliśmy wraz z zapowiedzią zwołania Soboru Watykańskiego II, a następnie z ogłoszenia takich dokumentów, jak: Lumen gentium, Gaudium et spes oraz Dei Verbum, a zwłaszcza Dekretu o ekumenizmie Unitatis redintegratio. Miał rację prof. A. Skowronek, kiedy pisał w 1983 r. Postowie do autobiografii Todda o Marcinie Lutrze, stwierdzając, iż w posoborowych czasach Marcin Luter właściwie przestał być przedmiotem zainteresowań wąskiej grupy teologów, gdyż obecne badania nad nim od 50 lat wpisują się w jego obraz i są prowadzone zarówno z mandatu Kościoła rzymskokatolickiego, jak i ewangelicko-luterańskiego, czego owocem są przecież dwa niezwykłe dokumenty, które usiłowano przypomnieć, a które prowadzą „od sporu do pojednania”, „od konfliktu do komunii”, czyli od 500-lecia urodzin dra Marcina Lutra do 500-lecia upamiętnienia Reformacji.

Dlatego w miejsce kreowania nowego obrazu M. Lutra, co zresztą nie było moim celem, niech znajdzie w niniejszym przedłożeniu swoje miejsce fragment przemówienia kard. Jana Willebrandsa wygłoszonego podczas V Zgromadzenia Ogólnego ŚFL: „Któż mógłby dzisiaj zaprzeczyć, że Marcin Luter był osobowością głęboko religijną, że szczerze i z oddaniem zgłębiał orędzie Ewangelii? Któż mógłby zaprzeczyć, że on, który tyle trudności przysporzył Kościołowi rzymskokatolickiemu i Stolicy Apostolskiej, nie można tego - w imię prawdy nie wyznać, że pozostał wierny cennemu dziedzictwu starej katolickiej wiary? Owszem, czyż sam II Sobór Watykański nie sformułował takich postulatów, jakie

${ }^{17}$ A. SKowronek, Marcin Luter - ani kacerz, ani święty. Postowie, w: J.M. TodD, Marcin Luter, $285-286$. 
m.in. wysunął Marcin Luter, by przez nie dzisiaj lepiej wyrazić niektóre aspekty chrześcijańskiej wiary i życia? Jeśli można to stwierdzić mimo wszelkich różnic, mamy podstawę do wielkiej radości i nadziei"18.

\section{Bibliografia}

Congar Y., Chrétiens désunis. Principes d'un „oecuménisme catholique”, Paris 1937.

Congar Y., Chrétiens en dialogue, Paris 1964.

Congar Y., Vraie et fausse réforme dans l'Eglise, Paris 1949.

Deklaracja o usprawiedliwieniu: historia powstania, tekst deklaracji, opinie, komentarze, Bielsko-Biała 2000.

Jedność przed nami. Raport Wspólnej Komisji Rzymskokatolicko-Ewangelicko-luterańskiej (1984), w: K. KARSKI, S.C. NAPIÓRKOwsKi (red.), Blizejej wspólnoty. Katolicy i luteranie w dialogu 1965-2000, Lublin 2003, s. 283-345.

Kościót i usprawiedliwienie. Rozumienie Kościoła w świetle nauki o usprawiedliwieniu. Raport międzywyznaniowego dialogu luterańsko-rzymskokatolickiego (1993), w: K. KARSKI, S.C. NAPIÓRKOWSKI (red.), Bliżej wspólnoty. Katolicy i luteranie $w$ dialogu 1965-2000, Lublin 2003, s. 361-481.

Luterańsko-Rzymskokatolicka Komisja Dialogu ds. Jedności, Od konfliktu do Komunii. Luterańsko-katolickie upamiętnienie reformacji w 2017 roku, thum. D. Bruncz, wyd. drugie poprawione, Dzięgielów 2017.

Marcin Luter - świadek Jezusa Chrystusa. Stowo Wspólnej Komisji Rzymskokatolicko - Ewangelicko-luterańskiej z okazji 500-lecia urodzin Marcina Lutra (1983), w: Bliżej wspólnoty. Katolicy i luteranie w dialogu 1965-2000, Lublin 2003, s. 274-281.

Navarro J.B., Luter Marcin, w: Tenże, Ekumenizm. Maty słownik, thum. E. Burska, Warszawa 2007, s. 199-201.

Niemiec M., Nauka o usprawiedliwieniu $w$ dialogu luterańsko rzymskokatolickim, Bielsko-Biała 2011.

Nossol A., Ekumeniczne elementy teologii M. Lutra, w: E. OŁtarzewsKa-WiEja (red.), Z problemów reformacji, t. VI, Bielsko-Biała 1993, s. 12-22.

Nossol A., Ekumenizm jako imperatyw chrześcijańskiego sumienia, Opole 2000. SkowroneK A., Marcin Luter - ani kacerz, ani święty. Posłowie, w: J.M. Todd, Marcin Luter, tłum. T. Szafrański, Warszawa 1983, s. 283-298.

\footnotetext{
${ }^{18}$ Cyt. za: Marcin Luter - świadek Jezusa Chrystus, nr 23.
} 
Wspólna deklaracja w sprawie nauki o usprawiedliwieniu (1999), w: K. KARSKI, S.C. NAPIÓRKowsKi (red.), Bliżej Wspólnoty. Katolicy i luteranie w dialogu 1965-2000, Lublin 2003, s. 499-523.

Wszyscy pod jednym Chrystusem. Stanowisko Wspólnej Komisji Rzymskokatolicko-Ewangelicko-luterańskiej wobec Konfesji Augsburskiej (1980), w: K. KARSKI, S.C. NAPIÓRKOWSKI (red.), Bliżej Wspólnoty. Katolicy i luteranie w dialogu 1965-2000, Lublin 2003, s. 229-236. 